\title{
Midwives Complience, Mother And Child Health Book, And Mother's Health
}

\author{
Fitnaningsih Endang Cahyawati ${ }^{1, *}$, Septiana Nurmalitasari ${ }^{2}$ \\ 1,2 University of Aisyiyah Yogyakarta, West Ringroad 63 Street Nogotirto, Gamping Sleman 55292, Yogyakarta, \\ Indonesia \\ ${ }^{1}$ fitnaningsihbidan@gmail.com* \\ *corresponding author \\ Submission date: 10 Juli 2020, Receipt date: 11 Juli 2020, Publication date: 1 November 2020
}

\begin{abstract}
The Maternal and Child Health Book (MCH Handbook) contains maternal (pregnant, childbirth and postpartum) health records and children (newborns to 6 year old children) as well as various information on how to maintain and care for the health of mothers and children. Based on the 2012 Indonesia Demographic Health Survey (IDHS), the maternal mortality rate (related to pregnancy, childbirth and childbirth) was 359 per 100,000 live births. This study aims to determine the compliance of the MCH handbook by midwives in early detection of high risk of pregnancy in the Kasihan 1 Health Center, Bantul Regency. This study used a descriptive quantitative research design. The variable in this study consisted of one variable, namely compliance with the book of MCH handbook by Midwife in early detection of high risk of pregnancy. The sampling technique in this study was total sampling, with a sample of 9 midwives. The results showed that the compliance of midwives in completing MCH handbooks at the Puskesmas Kasihan 1 Bantul District was mostly obedient with 6 KIA midwives with a percentage of $66.7 \%$ and not complying with 3 midwives with a percentage of $33.3 \%$. The suitability of midwives in filling MCH books at the Puskesmas Kasihan 1 Bantul Regency was mostly according to $41 \mathrm{MCH}$ books with a percentage of $68.3 \%$ and not according to $19 \mathrm{MCH}$ books with a percentage of $31.7 \%$. The next researcher is expected to be able to conduct a complete research thoroughly the factors that influence the completeness of the MCH handbook by observing and interviewing midwives.
\end{abstract}

Keywords: Midwives, Compliance in filling in MCH Books, High Risk Pregnancy

\section{INTRODUCTION}

According to (UNICEF, 2012), the maternal mortality rate in several ASEAN countries states that Indonesia is one of the countries with a relatively high maternal mortality rate, namely 600 per 100,000 live births (1). Based on the 2012 Indonesian Health Demographic Survey (IDHS), the maternal mortality rate (related to pregnancy, childbirth and postpartum) was 359 per 100,000 live births. This figure is still quite high when compared to neighboring countries in Southeast Asia (2).Then, in the Special Region of Yogyakarta, the maternal mortality rate in 2015 was 29 per 100,000 live births. In Bantul district in 2015 there were 16 cases, Gunungkidul district 7 cases, Kulon Progo district 2 cases, Sleman district 4 cases. Bantul Regency in 2015, is the first in line with the maternal mortality rate. The causes of maternal mortality in Bantul are severe preeclampsia (36\%), bleeding (36\%), pulmonary tuberculosis (48\%), amniotic fluid embolism (9\%) (3). Then, midwives are the spearhead of Maternal and 
Child Health, this is evident that as many as $87.8 \%$ of pregnant women choose midwives to check their pregnancies and $52.5 \%$ are used for antenatal care facilities are independent midwife practices, the rest are Puskesmas / Pustu $(16,6 \%)$ and Posyandu $(10.0 \%)$ and this is also seen in all provinces (4). Based on the decree of the Minister of Health of the Republic of Indonesia 284 / MENKES / SKIII / 2004 concerning the Maternal and Child Health (KIA) book, it is stated that the KIA book is a tool for early detection of maternal and child disorders or problems. The correct application of the Maternal and Child Health (KIA) book can increase the knowledge of pregnant women, empower families and communities to monitor the health of pregnant women and know how to detect early pregnancy with risks and get services according to standards (5). In a preliminary study conducted at Puskesmas Kasihan 1 Bantul, 9 data were obtained from the number of midwives who worked at Kasihan 1 Bantul Health Center, 302 pregnant women who had their pregnancies checked from January to December 2017, and 45 high-risk pregnant women. people consisting of PE / PEB, Hypertension, Anemia, History of SC, and Presbo. Therefore, this study aims to determine compliance with the filling of the $\mathrm{MCH}$ Handbook by midwives in early detection of high risk pregnancy at Puskesmas Kasihan I, Bantul Regency.

\section{RESEARCH METHODS}

This research is a descriptive quantitative study with a cross-sectional research design. The sample used by researchers was all midwives who worked at Puskesmas Kasihan 1 Bantul as many as 9 midwives who were taken by using the total sampling technique.

The instrument in this study or the measuring instrument used for data collection was a checklist. The checklist in this study contains the contents of the MCH booklet for pregnant women written by midwives. To measure the compliance variable of midwives in completing the $\mathrm{MCH}$ Handbook for high risk pregnancy screening is a Guttman scale checkist which consists of 2 (two) choices, namely "Yes" or "No" and "True" or "False" with a weighted score (1). or (0) in accordance with the behavior that is positive (favorable) or that is negative (unfaforable).

Then for the compliance checklist, it was measured by filling in the complete $\mathrm{MCH}$ booklet, namely the pregnancy examination service for 3 visits. In measuring compliance with the complete $\mathrm{MCH}$ handbook filling, if the value of completing the $\mathrm{MCH}$ booklet is $\geq 60 \%$, and if the completion of the KIA booklet is $<60 \%$, it is necessary to increase the development of health personnel by the Head of the Puskesmas and the coordinating midwife and the person in charge of the program related to the KIA book of the District Health Office / City.

Assessing the level of completeness of filling in the $\mathrm{MCH}$ Handbook for pregnant, childbirth and childbirth mothers on the technical guidelines for the use of the 2015 MCH Handbook, namely the following formula: (Number of MCH Handbooks for infants, toddlers and preschoolers that are completely filled in) / (60 babies, toddlers and preschoolers ) x $100 \%$.

Data analysis was carried out through descriptive analysis to bring up the frequency and percentage of research variables using the SPSS version 17 statistical application. 
RESULTS AND DISCUSSION

Table 1. Frequency Distribution of Midwives Age and Education Characteristics

\begin{tabular}{lcc}
\hline \multicolumn{1}{c}{ Characteristics } & F & $\%$ \\
\hline Ages & 6 & $66,7 \%$ \\
a. 25 years -39 years & 3 & $33,3 \%$ \\
b. $\geq 40$ years & 9 & $100 \%$ \\
Total & & \\
\hline Education & 7 & $77,8 \%$ \\
a. D3 & 2 & $22,2 \%$ \\
b. D4 & 9 & $100 \%$ \\
Total & &
\end{tabular}

The results of this study indicate that most midwives aged 25 years - 39 years were 6 people with a percentage of $66.7 \%$ and midwives aged $\geq 40$ years were 3 people with a percentage of $33.3 \%$. According to Notoatmodjo (2012), age affects a behavior, especially one's obedience. The more old enough, the level of maturity and strength of a person will be more mature in thinking and working. Someone who is more mature will be more trusted than someone who is not mature enough. The more mature a person is, the more mature and regular way of thinking is to do an action (6).

Then, most of the midwife's latest education was D3, amounting to 7 people with a percentage of $77.8 \%$ and D4 midwives amounting to 2 people with a percentage of $22.2 \%$. According to Niven (2008), one of the factors that influence compliance is education. Education is a conscious and planned effort to create an atmosphere of learning and the learning process so that students actively develop their potential. The high level of education of a midwife can increase compliance in carrying out its obligations, as long as that education is active education (7).

A person's high education can affect their knowledge. The higher the education, the higher the person's knowledge, such as research conducted by Anasari (2015), the high education of midwives with good knowledge of midwives on completeness of $\mathrm{MCH}$ book filling is $69.6 \%$ greater than less knowledge, namely $20 \%$ (8) . Behavior based on education and knowledge will be more meaningful than behavior that is not based on knowledge and education (9).

Table 2. Frequency distribution of compliance with MCH handbook filling

\begin{tabular}{lccc}
\hline & Compliance & F & \% \\
\hline Yes & 6 & $66,7 \%$ \\
Not Compliance & 3 & $33,3 \%$ \\
Total & 9 & $100 \%$ \\
\hline
\end{tabular}

Source: Primary Data (2018)

Midwives at Puskesmas Kasihan 1 Bantul were compliant with filling out the $\mathrm{MCH}$ handbook with a percentage of $66.7 \%$ and as many as 3 midwives were not obedient in filling out the $\mathrm{MCH}$ handbook with a percentage of $33.3 \%$. This is in accordance with the technical instructions for the use of the KIA book on compliance with the filling of the $\mathrm{MCH}$ book, which is $\geq 60 \%$,

Some of the midwives who were obedient in filling out the $\mathrm{MCH}$ handbook were aged $\geq 40$ years and with a D4 education. In this study, there were still midwives who were not obedient in filling out the $\mathrm{MCH}$ booklet and aged 25 to 39 years. Compliance can be influenced by several factors, namely age, education, modification 
of environmental and social factors, changes in procedural models, knowledge, attitudes, and age (7).

Age affects a behavior, especially one's obedience. The more old enough, the level of maturity and strength of a person will be more mature in thinking and working. Someone who is more mature will be more trusted than someone who is not mature enough. The more mature a person is, the more mature and orderly he will think in doing an action (6).

In one's compliance, education also affects behavior, because a person's higher education can affect their knowledge. The higher the education, the higher the person's knowledge, such as research conducted by Anasari (2012), the high education of midwives with good knowledge of midwives on completeness of $\mathrm{MCH}$ book filling is $69.6 \%$ greater than less knowledge, namely $20 \%$ (8). Behavior based on education and knowledge will be more meaningful than behavior that is not based on knowledge and education (9).

Research conducted by Ristrini and Oktarina (2015), there are 2 factors that affect midwives in filling out the $\mathrm{MCH}$ booklet, namely non-financial factors that encourage midwives to complete the filling in, most $(91.7 \%)$ state because of their responsibility as a midwife, while financial factors are involved. encouraging midwives to complete filling in the majority $(50.0 \%)$ of the incentives from the $\mathrm{MCH}$ program (10). Anasari (2015) states in his research that the completeness of filling in the $\mathrm{MCH}$ book can be influenced by knowledge, perception of supervision, motivation, support for facilities, workload (8).

Table 3. Frequency distribution of the suitability books filling of KIA

\begin{tabular}{lccc}
\hline & Kesesuaian & Frekuensi & \% \\
\hline Ya & 41 & $68,3 \%$ \\
Tidak & 19 & $31,7 \%$ \\
Total & 60 & $100 \%$ \\
\hline
\end{tabular}

Source: Primary Data (2018)

Completing the complete MCH Handbook can help midwives and other health professionals detect high risk of pregnancy early. The completeness of filling out the $\mathrm{MCH}$ book is very important as stated in the Yogyakarta Regulation Number 24 of 2014 article 5 regarding the use of the KIA book in MCH services, including:

a. As a guidebook that is owned by mothers and children which contains information and records of maternal and child health

b. As a monitoring tool for maternal and child health that is owned by the family and is used in all health facilities

c. As a combination of the child's mother's health card from pregnancy to 5 (five) years of age.

d. As the only means of recording maternal and child health services from pregnancy, childbirth and during the postpartum period until the baby is born at the age of 5 (five) years, including family planning services, immunization, nutrition and child development.

e. As a health education tool and health communication tool

In the part of the MCH Handbook that is not properly written or not written clearly, namely the filling of the fetal heart rate, the location of the fetus, the writing is not in accordance with the technical instructions for writing the $\mathrm{MCH}$ book so it cannot describe the actual condition of the midwife. The value of completing the $\mathrm{MCH}$ booklet 
is in accordance with the complete $\mathrm{MCH}$ book filling if the value of completing the KIA book filling is $\geq 60 \%$ (11)

The results of this study are in accordance with the technical guidelines for the use of the KIA book, that the value of the $\mathrm{MCH}$ book filling is in accordance with the complete $\mathrm{MCH}$ book filling, namely $\geq 60 \%$. However, there are still some research results that show that the filling out of the $\mathrm{MCH}$ handbook is not in accordance with the technical instructions for filling out the $\mathrm{MCH}$ handbook. This can occur with the existence of several motivational factors for the midwife to use the $\mathrm{MCH}$ handbook, midwife knowledge, workload, and support for facilities (12).

Research conducted by Ristriani and Oktarina (2015), factors affecting the suitability of the $\mathrm{MCH}$ booklet filling include motivation, workload, supervision and training of midwives. For good motivation, namely $(66.4 \%)$, workload $((83.3 \%)$, supervision $(53.8 \%)$ and training of midwives in filling out the $\mathrm{MCH}$ booklet $(41.7 \%)$ (10).

During pregnancy services as stated in the Regulation of the Minister of Health of the Republic of Indonesia Number 97 of 2014 article 13 paragraph 3, health services during pregnancy are carried out four visits during pregnancy must be carried out according to standards and recorded in the KIA book (13).

\section{CONCLUSION}

The compliance of midwives in filling out the $\mathrm{MCH}$ handbook at Puskesmas Kasihan 1, Bantul Regency, was that 6 midwives were obedient in filling out the MCH handbook with a percentage of $66.7 \%$ and as many as 3 midwives were not obedient in filling out the MCH booklet with a percentage of $33.3 \%$. The suitability of midwives in filling out the $\mathrm{MCH}$ handbook at Puskesmas Kasihan 1 Bantul Regency was 41 KIA books according to the technical manual for the use of the KIA book with a percentage of $68.3 \%$ and as many as 19 KIA books that did not match the technical instructions for using the KIA book with a percentage of $31.7 \%$.

This research is expected to help midwives to further improve the accuracy of midwives in filling out the $\mathrm{MCH}$ handbook completely and in accordance with the existing technical guidelines for using the $\mathrm{MCH}$ handbook.

The next researcher is expected to be able to conduct a complete and comprehensive research on the factors that influence the completeness of the $\mathrm{MCH}$ booklet filling by observing and interviewing midwives.

\section{REFERENCES}

Anasari, T. (2015). Faktor-faktor Yang Mempengaruhi Kelengkapan Pengisian Buku KIA Oleh Bidan Dalam Deteksi Dini Resiko Tinggi Kehamilan Di Puskesmas Kabupaten Banyumas Tahun 2012. https://www.fkm.undip.ac.id/.../sisteminformasi-manajemen-2013-11-10. (Diakses tanggal 30 Oktober 2017).

Gibson, M. (2008). Manajemen Sumber Daya Manusia. Cetakan ke dua. Jakarta : Erlangga.

Hutrianti, I. (2016). Gambaran Tingkat pengetahuan Ibu Hamil Tentang Buku Kesehatan Ibu dan Anak (KIA) Di Puskesmas Jetis II Kabupaten Bantul. Yogyakarta : STIKes Jendral A.Yani.

Kemenkes RI. (2013). Pusat Data dan Informasi Kementrian RI. Jakarta : Kemenkes

Kemenkes RI. (2015). Buku Kesehatan Ibu dan Anak (KIA). Jakarta : Kemenkes

Kemenkes RI. (2016). Juknis Buku Kesehatan Ibu dan Anak (KIA). Jakarta : Kemenkes 
Kemenkes RI. (2014). Rencana Pembangunan Jangka Menengah Nasional 2015-2019. Jakarta : Kemenkes.

Niven. (2008). Psikologi Kesehatan Pengantar Untuk Perawat dan Profesional Kesehatan. Jakarta : EGC

Notoatmodjo, S. (2012). Promosi Kesehatan dan Perilaku Kesehatan. Jakarta : Renika Cipta.

Profil Kesehatan Indonesia. (2013). Buku Profil Kesehatan Indonesia Tahun 2013. Jakarta : Kemenkes

Profil Kesehatan Bantul. (2015). Buku Profil Kesehatan Kabupaten Bantul Tahun 2015. Bantul : Dinkes Bantul

Ristriani dan Oktarina. (2014). Upaya Peningkatakan Deteksi Dini Kehamilan Melalui Kelengkapan Pengisian Buku KIA oleh Bidan di Bangkalan Jawa Timur tahun 2013

Unicef. (2012). Kesehatan Ibu \& Anak. https://www.unicef.org/indonesia/id/A5__B_Ringkasan_Kajian_Kesehatan_REV.pdf (Diakses tanggal 13 Oktober 2017). 